\title{
Dundee Meeting of the British Association
}

$\mathrm{T}$ HE meeting of the British Association in Dundee, which will run from August 30 until September 6, will be the third to be held in that city. The preliminary programme has just been issued. It is stated that for Dundee the present year is one of civic jubilee, for the town "attained the dignity of a city" in 1889: this coincidence with the meeting of the Association will not be overlooked. In referring to the previous meetings, mention is made of that in 1912 as "the occasion of a splendid act of generosity by a citizen of Dundee, the late Sir James Caird, whose gift of $£ 11,000$ to the funds of the Association enabled it to commemorate his name in the Caird Fund" for research.

The requirements of the Association in the way of accommodation for meetings and other functions will be more easily met this year than they were in 1912. The great hall which bears Caird's name has been built since that date: it will amply house the inaugural meeting on August 30, at which the president, Sir Albert Seward, will give his address on "The Western Isles through the Mists of Ages." The same hall will be the scene of a civic reception in the evening of August 31 , of a graduation at which the University of St. Andrews will confer honorary degrees, on September 4, and of other items in the programme. The Reception Room and offices will be located in the Training College; the Victoria Art Galleries, which provided the Reception Room in 1912, will on the present occasion house a special exhibition of pictures, some from the city's permanent collection, others on loan from private collections in the district. The sections of the Association will be conveniently established, mostly in the University College, which immediately adjoins the Training College, and some in other buildings not far away.

The subjects of the presidential addresses in the sections, so far as they are announced, are as follows: Section A: Mr. R. S. Whipple on "Instruments in Science and Industry" ; Section B : Prof. E. K. Rideal on "Film Reactions as a New Approach to Biology"; Section C: Prof. H. H. Read on "Metamorphism and Igneous Activity"; Section D: Prof. J. Ritchie on "Perspectives in Evolution"; Section G: Mr. H. E. Wimperis on "The Future of Flight"; Section H : Prof. W. E. Le Gros Clark on "The Scope and Limitations of Physical Anthropology" ; Section I : Prof. D. Burns on "The Assessment of Physical Fitness"; Section J : Mr. R. J. Bartlett on "Measurement in Psychology"; Section K : Prof. D. Thoday on "The Interpretation of Plant Structure"' ; Section L : Dr. A. P. M. Fleming on "Education in Industry"; Section M: Sir Thomas Middleton on "Practice with Soience. The Farmer's Position and the Scientific Worker's Programme".

Among other subjects announced for discussion in the sections are: In Section A, television, problems of high-speed flight, the surface temperature of stars and high-temperature problems. Sections A and $\mathbf{B}$ will join in a discussion on artificial radio elements. Section $B$ will deal with light alloys and with intramolecular changes, and will join with Section $I$ in discussing tissue respiration. Section $\mathrm{C}$ will deal, as usual at an opening meeting, with local geology, and in this connexion it may be mentioned that a sectional excursion will be held after the meeting during September 7-11, covering Edinburgh and a district from the coast to the north-east, to the hills to the south-west of that city. Section $\mathrm{C}$ will deal also with the raised beaches of Forth and Tay, and with the Old Red Sandstone-Carboniferous boundary. Section D will discuss the natural history of salmon and trout, and there will be an exhibition of biological films. Another subject to be dealt with by this section is problems of freshwater biology. Section $\mathrm{E}$ will discuss the national atlas which is at present under the consideration of a committee of the Section. Speakers from other sections concerned will take part in the discussion. Section F will deal with various Scottish economic problems. The programme of Section G includes problems of transatlantic aviation and air conditioning. Section $\mathbf{H}$ will return to the subject of the teaching of anthropology and will join with Section I in the discussion of nutrition and physique. In Section I this last topic will be associated with that of the assessment of physical fitness, and the Section will also deal with the problem of pain. This Section will hold a day's session at $\mathbf{S t}$. Andrews. Section $\mathrm{L}$ announces discussions on education as a preparation for industry, on educational research in Scotland, and on the Spens Report. Section M will review the subjects of grass conservation and seed potato growing.

Two special sessions under the auspices of the appropriate sections jointly, and a local committee, will deal with scientific aspects of the cultivation and treatment of jute and with problems associated with the jute industry. 
The Conference of Delegates of Corresponding Societies will be presided over by Prof. H. L. Hawkins, who will give an address on "Local Scientific Societies and the Community".

The new Division for the Social and International Relations of Science, established last year at the Cambridge meeting, announces an afternoon session for papers and discussion on the co-ordination of scientific research, and on population, and it is understood that the possibility of a discussion on international co-operation in science is also under consideration. An evening meeting on Sunday, September 3, will hear an address from Sir Richard Gregory, chairman of the Division, on science and social ethics, and on Wednesday morning, September 6, a session of the Division will be devoted to a discussion on nutrition, which will form a complement to sectional discussions in this field already mentioned.

A new feature of British Association meetings will be the delivery by Dr. Isaiah Bowman, president of Johns Hopkins University, of the first of the lectures to be given under the arrangement concluded last year with the American Association for the Advancement of Science, by which, in alternate years, a speaker from America is to be invited by the British Association, and one from Great Britain by the American Association. Dr. Bowman has chosen as his subject "Science and Social Pioneering". A number of public lectures will be given not only in Dundee, but also in neighbouring towns. In this connexion it is of interest to recall that it was at the Dundee meeting in 1867 that the first lecture to the 'operative classes' was given, an annual series out of which the present public lectures developed : moreover, it was at the Dundee meeting in 1912 that for the first time, in response to public demand, more than one such lecture was given, a practice which has become common since that time.

The customary full list of excursions is announced -those on Saturday will include Blair Atholl, Dunfermline, St. Andrews, Braemar and other places, and there will be many visits to works and places and institutions of special interest to individual sections. Garden parties and a dance are announced, and the Dundee Horticultural Society will hold its flower show during the period of the meeting; the president of the Association will perform the opening ceremony.

The paragraph on accommodation for visitors begins with the frank statement that hotel accommodation in Dundee is rather limited, but a local committee is actively at work on the whole question of meeting visiting members' requirements, and there need be no fear of any difficulty if members will make known their wishes in accordance with the directions in the programme.
The programme includes a list of all hotels and boarding-houses in Dundee and neighbouring places, and a list of lodging houses is in preparation. There will be a limited amount of accommodation in the hostels attached to University College, and the Medical School, and it should be specially observed that students' residence halls of the University of St. Andrews will be open to receive visitors; it is hoped that a service of special trains will be worked for the convenience of members staying in that town.

The announcements concerning publications include a reference to an important change decided upon at the Cambridge meeting. As from October 1939, the Reports of the Association will be published quarterly under the title of "The Advancement of Science" and the annual volume hitherto issued will be discontinued. So also will the collection of presidential addresses which have been issued at the time of the meeting under the title of "The Advancement of Science", which title will now be transferred to the new quarterly. It is stated, however, that individual addresses will be on sale separately during the meeting.

The preliminary programme is ascompanied by an appeal from the general treasurer for an extension of membership of the Association. It is common knowledge that any person can, and very many do, take up membership only for the year of a particular meeting at which it is intended to be present: in particular, special efforts are always made to ensure that all interested residents in the locality of the annual meeting are given the opportunity to do this. But it is rather startling to learn from the present appeal that "of those who attend the annual meetings (apart from life members) only a small proportion-about onequarter-are regular annual subscribers". The Association deserves a wider basis of permanent support than that, by a largely increased number whether of regular annual subscribers or of life members. It is pointed out in the appeal that "during the past few years the British Association has not hesitated to extend in fresh directions its activities for the advancement of science". Examples are given. In a reference to the new Division for the Social and International Relations of Science, established last year, it is stated that "the fields of activity already opened to view indicate that with more ample resources the Association will be able to undertake, through the Division, new work of national and international importance". Reference is made to the recent scientific delegation to India, an example likely to be followed elsewhere; to the arrangement for exchange of lecturers between the British and American Associations, made last year, and to various other opportunities which the Association 
now possesses, within the framework of its constitution, to advance science, provided only that increased financial support is forthcoming. "These wide potentialities", the appeal states, "have all emerged in recent years; but there must always be borne in mind the field of scientific research and inquiry in which the Association has honourably laboured almost since its foundation. The ability to make grants for research is of the essence of its being, and to maintain and strengthen this activity is one of the first tasks of every successive General Treasurer."

The appeal deserves success, and it is to be hoped that it will achieve it. Its professed object, as has been said, is the extension of membership ; but well-disposed persons will not overlook the possibility of strengthening the financial foundations of the Association by other means.

\section{Obituary Notices}

\section{Prof. C. M. Jessop}

$\mathrm{C}$ HARLES MINSHALL JESSOP, who died on March 9, was born on June 13, 1861. His father was vice-principal of Cheshunt Theological College, and it may be to this that he owed his strong religious views. Jessop was educated at King's College School, London, and Clare College, Cambridge. He was bracketed seventh wrangler in the mathematical tripos of 1885 along with James Harkness and Henry Stroud. Harkness was afterwards the joint author of Harkness and Morley's "Theory of Functions", and Stroud became, later, as professor of physics, Jessop's colleague in the Newcastle Division of the University of Durham. In the same year (1885) Jessop was elected a fellow of Clare.

After holding various teaching posts in schools, Jessop was in 1893 appointed lecturer in mathematics at the Durham College of Science, Newcastle-uponTyne, now King's College ; in 1903 he was advanced to be professor of mathematics in the same College, a post which he held until his retirement in 1928 .

Jessop's main mathematical interest was in geometry, and he frequently deplored the diversion of interest in Great Britain from geometry to other branches of mathematics. His contribution to the subject was his two books. The first, published in 1903, was a "Treatise on the Line Complex". Apart from J. H. Grace's account of the subject in the tenth edition of the "Encyclopædia Britannica", this was the first full treatment in English. It gave a com. plete discussion of the development of the subject at that time.

The second book was on "Quartic Surfaces with Singular Points", which appeared in 1912. This was welcomed as a valuable introduction to some of the latest results obtained by geometricians and at once took its place among the standard English treatises.

Jessop also published several smaller books, of which the most popular was the "Elementary Treatise on Trigonometry" which appeared in 1893, a joint work with $\mathrm{E}$. W. Hobson.

Jessop had a fine appreciation of good mathematical style. He valued the subject for its own sake and was somewhat contemptuous of mathematics as a handmaid to the sciences. He was an inspiring teacher, especially to advanced students, and many hundreds owe their interest in mathematics to his able presentation.

\section{Dr. Alexander Hetherwick, C.B.E.}

We regret to record the death of the Rev. Alexander Hetherwick, for many years prominent as a missionary in Central Africa, which took place in Aberdeen on April 3 in his seventy-ninth year.

Alexander Hetherwick was born on April 12, 1860, and graduated from the University of Aberdeen with high honours in classics, mathematics, and theology, winning the Arnot Prize for oxperimental physics, and being Simpson mathematical prizeman.

At twenty-three years of age, Hetherwick volun. teered for work with the mission of the Church of Scotland in Central Africa under Dr. Clement Scott at Blantyre. Five years later, in 1888 , he succeeded Scott as head of the mission, a position he retained until his retirement in 1928. On his arrival in Central Africa the country, which afterwards became Nyasaland, was inhabited by pagan tribes dominated by the warlike Angoni, an intrusive immigrant offshoot of the Zulu stock; but his influence soon made itself felt. On his retirement he was Moderator of the Synod of Central Africa, in which the Presbyteries of Blantyre and Livingstonia, with those of the Dutch Mission, comprised some 40,000 members drawn from these pagan tribes.

It was not, however, for its Christianizing influence in the narrower sense that Hetherwick's work was remarkable. Under his guidance the Scottish Mission was conspicuous for its endeavour in instructing the native in handiwork and agriculture, and for its work among them in medicine and hygiene. Dr. Hetherwick himself was the foremost authority on the languages of the country. $\mathrm{He}$ translated the New Testament into the language of the Yao and was chairman of the board for the translation of the Bible into Nyanja. He wrote handbooks of the principal languages, and on his return to Scotland took up the revision of Scott's great dictionary of Nyanja. His knowledge of native customs and institutions was no less profound than his knowledge of their languages; and he was in those early days one of the principal sources of knowledge of the subject, on which he was a contributor to the Journal of the Royal Anthropological Institute. Dr. Hetherwick was twice a member of the Legislative Council, and received the thanks of the Colonial Office and the C.B.E. for his services to native welfare. 